\title{
Some Full Blood Count Parameters among Hypertensive Patients Attending Specialist Hospital, Sokoto, Nigeria
}

\author{
Osaro Erhabor ${ }^{1 *}$, Abdullahi Shehu ${ }^{1}$, Tosan Erhabor ${ }^{2}$, Teddy Charles Adias ${ }^{3}$, \\ Ikechukwu Polycarp Iwueke ${ }^{4}$ \\ ${ }^{1}$ Department of Haematology, School of Medical Laboratory Science, Usmanu Danfodiyo University Sokoto, Sokoto, Nigeria \\ ${ }^{2}$ Medical Laboratory Science Council of Nigeria, Abuja, Nigeria \\ ${ }^{3}$ Federal University Otuoke, Otuoke, Nigeria \\ ${ }^{4}$ Pathology Department, Federal Neuro-Psychiatric Hospital, Sokoto, Nigeria \\ Email: *n_osaro@yahoo.com
}

How to cite this paper: Erhabor, O., Shehu, A., Erhabor, T., Adias, T.C. and Iwueke, I.P. (2019) Some Full Blood Count Parameters among Hypertensive Patients Attending Specialist Hospital, Sokoto, Nigeria. Open Journal of Blood Diseases, 9, 77-91

https://doi.org/10.4236/ojbd.2019.94008

Received: July 26, 2019

Accepted: October 20, 2019

Published: October 23, 2019

Copyright $\odot 2019$ by author(s) and Scientific Research Publishing Inc. This work is licensed under the Creative Commons Attribution International License (CC BY 4.0).

http://creativecommons.org/licenses/by/4.0/

\begin{abstract}
Hypertension (HTN) is a major health problem worldwide. It can lead to cardiovascular disease and functional disturbances including haematological parameters. Full blood count (FBC) parameters of a total of 60 consecutively-recruited hypertensive subjects and 30 age-matched non-hypertensive controls were studied between June and September, 2018. Ethylene Diamine Tetra Acetic Acid (EDTA) anticoagulated blood and serum from subjects and control participants were analyzed for FBC. The total white cell count (WBC), packed cell volume (PCV) haemoglobin ( $\mathrm{Hb})$, neutrophils and eosinophils were significantly lower among hypertensive subjects compared to non-hypertensive controls $(\mathrm{p}<0.01, \mathrm{p}=0.02, \mathrm{p}<0.01, \mathrm{p}<0.01, \mathrm{p}<0.01)$ respectively. The red cell count, monocyte and lymphocyte count were significantly higher among the hypertensive subjects compared to controls $(\mathrm{p}=$ 0.00 ). There was a statistically significant variation in the haemoglobin, platelet count and red cell distribution width among the hypertensive subjects based on the stage of the hypertensive disease $(\mathrm{p}<0.01, \mathrm{p}=0.01$ and $\mathrm{p}<$ $0.01)$ respectively. The haematological parameters were compared among the hypertensive subjects based on age, gender and ethnicity. The PCV and platelet count were significantly higher among hypertensives $>40$-year-old compared to those $<40$ years of age $(\mathrm{p}=0.02$ and 0.01$)$ respectively. The $\mathrm{RBC}$ count was significantly higher among female compared to male hypertensives $(p=0.05)$. The haemoglobin and monocyte count were significantly higher among male compared to female hypertensives $(p=0.02$ and 0.04$)$ respectively. The monocyte count was significantly higher among hypertensive subjects of Hausa ethnic group compared to Fulani $(t=2.79, p<0.01)$. The
\end{abstract}


findings from this study indicates that the WBC, PCV, $\mathrm{Hb}$, neutrophils and eosinophils were significantly lower among hypertensive subjects compared to non-hypertensive controls. Stage of the disease, age, gender and ethnicity had a significant effect on the FBC parameters of the hypertensive patients. There is need to step up public enlightenment programme to educate hypertensive patients on the need for attending clinic regularly for effective follow up. It is recommended that facilities for the routine monitoring of FBC parameters among hypertensive in the area be provided.

\section{Keywords}

Full Blood Count, Hypertension, Specialist Hospital, Sokoto, Nigeria

\section{Introduction}

Hypertension, also known as high blood pressure or arterial hypertension is a chronic medical condition in which the blood pressure in the arteries is elevated. Blood pressure is expressed by two measurements, the systolic and diastolic pressures, which are the maximum and minimum pressures, respectively, in the arterial system. The systolic pressure occurs when the left ventricle is most contracted; the diastolic pressure occurs when the left ventricle is most relaxed prior to the next contraction. Normal blood pressure at rest is within the range of 100 - $140 \mathrm{mmHg}$ systolic and $60-90 \mathrm{mmHg}$ diastolic. Hypertension is present if the blood pressure is persistently at or above $140 / 90 \mathrm{mmHg}$ for most adults; different criteria apply to children [1]. Blood pressure falls during sleep and rises rapidly just before we wake up, which is when the risk of cardiovascular events is the highest. Therefore, a definition of hypertension is usually taken as that level of arterial blood pressure associated with doubling of long-term cardiovascular risk [2].

Hypertension has become a chronic condition and a major public health problem that adversely affects health status of individuals' families and communities [3]. However, globally, the burden of hypertension and other non-communicable diseases (NCDs) is rapidly increasing, and the African continent may be the most affected region in the world [4]. It is estimated that hypertension affects about 1 billion people all over the world and it is the main risk factor for many other cardiovascular diseases [5] [6] [7]. With an increasing adult population and changing lifestyle of Nigerians, the burden of hypertension may continue to increase as time unfolds [8] [9]. The prevalence of hypertension in Nigeria may form a substantial proportion of the total burden in Africa because of the large population of the country currently estimated to be over 170 million [5]. In Nigeria, the last two decades have seen a rise in the number of prevalence studies concerning hypertension and other non-communicable diseases [10] [11] [12] [13] [14].

Hypertension has been documented as a threat to the health of people in 
sub-Saharan Africa and a major contributor to morbidity and mortality in the sub-region [15]. The awareness of hypertension is low in Nigeria. Previous reports indicated awareness rates of $14.2 \%$ in rural areas [16] and $42 \%$ among market workers in Enugu State [17]. Awareness, treatment and control of hypertension were generally low with attendant high burden of hypertension related complications. The proportion of hypertensives on treatment in Nigeria is reported to be $21 \%$ ( $23.7 \%$ men, $17.5 \%$ women) [18] and $18.6 \%$ (19.0\% men, $18.4 \%$ women) [16].

Full blood count $(\mathrm{FBC})$ is also known as Complete Blood Count (CBC). It is one of the most common laboratory tests performed today. It gives information about the production of all blood cells and identifies the patient's oxygen carrying capacity through the evaluation of red blood cells (RBC) indices, haemoglobin and haematocrit. It also provides information about the immune system through the evaluation of white blood cells (WBC) count with differential. This test is helpful in the diagnosis of anaemia, certain cancers, infection, acute haemorrhagic states allergies and immune deficiencies as well as in the monitoring of side effects of certain drug that causes dyscrasias [19].

Hypertension is a highly prevalent factor for cardiovascular disease. It has become an increasingly common health problem worldwide because of increasing longevity and prevalence of contributing factors such as obesity, physical inactivity and unhealthy diet [20] [21]. The current prevalence in many developing countries, particularly in urban societies, is already as high as those seen in the developed countries [22] [23]. The population of global disease burden attributable to hypertension is substantial. Hypertension plays a major role in the development of cerebrovascular disease, cardiac and renal failure. Treating hypertension has been associated with about a $40 \%$ reduction in the risk of stroke and about a $15 \%$ reduction in risk of myocardial infection [24]. Hypertension remains a major challenge in Nigeria. The prevalence of hypertension in Nigeria has increased from $11.2 \%$ in the 1990 s [25] to $27.9 \%$ in 2010 in a rural community in the Niger Delta [26] and 22.6\% in 2009 among a suburban Christian community in Port Harcourt was $21.33 \%$ [27]. The prevalence of hypertension in rural communities in Rivers State [26] and Edo State [28] was 27.9\% and $20.2 \%$ respectively.

There is paucity of data of Full Blood Count Parameters among Hypertensive patients attending Specialist Hospital, Sokoto, Nigeria. The aim of this study is to determine the full blood count parameters among hypertensive patient in Sokoto, North Western, and Nigeria.

\section{Materials and Methods}

\subsection{Study Area}

The study was conducted in the Medicine Department of Specialist Hospital Sokoto and the samples were analyzed in the Department of Haematology and Blood Transfusion Science, Usmanu Danfodiyo University Teaching Hospital 
(UDUTH), Sokoto, Nigeria. The Department and the collaborating Specialist Hospital Sokoto have enabling environment (human and material endowment) to carry out this study. Sokoto State is located in the extreme North Western part of Nigeria, near to the confluence of the Sokoto River and the Rima River. With an annual average temperature of $28.3^{\circ} \mathrm{C}\left(82.9^{\circ} \mathrm{F}\right)$, Sokoto is on the whole, a very hot area. However, maximum daytime temperatures are for most of the year is generally under $40^{\circ} \mathrm{C}\left(113.0^{\circ} \mathrm{F}\right)$. The rainy season is from June to October during which showers are a daily occurrence. There two major seasons (wet and dry) are distinct. Report from the 2007 National Population Commission indicated that the State had a population of 3.6 million [29].

\subsection{Study Population}

The study enrolled 60 hypertensive patients both men and women attending the general outpatient clinic of Specialist Hospital Sokoto. Thirty non-hypertensive healthy aged-matched men and women (students and staff of Usmanu Danfodiyo University and Specialist Hospital Sokoto) were included as controls. The study was carried out between June and September, 2018.

\subsection{Inclusion Criteria}

All consenting adult patients with confirmed hypertension visiting the general outpatient clinic of Specialist Hospital Sokoto were consecutively recruited into the study.

\subsection{Exclusion Criteria}

All non-consenting and non-adult hypertensive subjects and non-hypertensive individuals were excluded from the study as subjects.

\subsection{Sample Size Determination}

Sample size determination for the study was calculated based on the prevalence reported from a previous study in Nigeria [30] using the following formulae:

$$
n=\frac{Z^{2} p q}{d^{2}}
$$

where;

$$
\begin{aligned}
& n=\text { Number of samples (sample size) } \\
& Z=\text { Standard normal deviate at } 95 \% \text { confidence interval }=1.96 \\
& p=\text { Prevalence from initial studies }=4.8 \%=0.048[30] \\
& d=\text { degree of confidence at }=5 \%=0.05 \\
& q=1-\mathrm{p}=1-0.048=0.952 \\
& \quad n=\frac{1.96^{2} \times 0.048 \times 0.952}{0.05^{2}}=\frac{3.8416 \times 0.0456}{0.0025}=70.07 \approx 70
\end{aligned}
$$

\subsection{Study Design}

This research was a case-control study involving confirmed hypertensive pa- 
tients as subjects. The patients were consecutively enrolled into the study. Qualitative data was elicited using structured interviewer administered questionnaire which include age, gender, socio-economic class of the parent and others. The socio-economic status was assessed based on income, education and occupation. It is usually broken into three categories (high, middle and low socio-economic status).

Quantitative data were obtained by estimating the manganese, zinc level and full blood count parameters which include packed cell volume, total leukocytes, neutrophil, eosinophil, basophil and monocytes count.

\subsection{Subject Selection}

The study involved individuals with a confirmed diagnosis of hypertension at the Internal Medicine Unit of Specialist Hospital Sokoto. The control samples were obtained from non-hypertensive individual as confirmed by the physician at the hospital. Following informed consent, a structured interviewer administered questionnaire was used to elicit data on subject's socio-economic and demographic characteristics. Ethical approval was obtained from the Hospital Ethical and Research Committee of Specialist Hospital Sokoto before commencement.

\subsection{Sample Collection and Processing}

About $3.0 \mathrm{ml}$ of venous blood was collected from each subject from a venipuncture site using $70 \%$ alcohol under aseptic conditions. One milliliter of blood was then delivered into sample bottles containing ethylene diamine tetra acetate (EDTA) and gently mixed immediately to prevent sample from clotting and 2.0 mls into plain sample bottle. The sample was then appropriately labeled. The EDTA anticoagulated blood was used for determination of complete blood count.

\subsection{Informed Consent}

Verbal informed consent was obtained from the parent and guardian prior to commencement of the study.

\subsection{Ethical Consideration}

Ethical approval for the study was obtained from Research and Ethical Committee of Specialist Hospital, Sokoto.

\subsection{Questionnaire}

A semi-structured interviewer-administered questionnaire was administered to all consenting participants to obtain information on their socio-demographic, nutritional and medical history.

\subsection{Sample Collection and Method of Analysis}

Two milliliters of blood were collected from each participant into EDTA bottle for full blood count estimation. These samples were tested in Haematology De- 
partments of Usmanu Danfodiyo University Teaching Hospital (UDUTH).

\subsection{Full Blood Count Estimation}

Full blood count was carried out using the five-part automated haematology analyser (Mythic 22 CT, 2008 Orphee, Switzerland). The analyzer, when the diluent is displayed by blood cells, causes a measurable change in resistance. The cells are allowed to pass through an aperture through which an electric current is flowing. Cell passing through the aperture displace the diluents; and being bad conductors of electricity, increases the resistance which is counted as a voltage pulse, which are converted to digital recording. The cell suspension is drawn through the aperture with the help of a vacuum pump into a system of tubing.

\subsection{Data Analysis}

Data obtained was entered into a statistical package (such as SPSS version 25) on a computer to define the nature of the distribution of data for each group. Statistical differences of data was analyzed using series of statistical analysis such a mean, standard deviation, t-test, ANOVA was used to compare the mean \pm SD of the full blood count and zinc and manganese level of hypertensive patients and the normal control subjects depending on the nature (categorical or continuous) and distribution of data (normal or non-normal). Probability ( $\mathrm{p} \leq 0.05)$ was used to determine the level of significant for all statistical analysis.

\section{Result}

The study investigated 60 hypertensive patients both men and women attending the general outpatient clinic of Specialist Hospital Sokoto. Thirty non-hypertensive healthy aged-matched men and women were monitored as controls. Table 1 shows the FBC among hypertensive subjects and controls. The White Cell Count (WBC), haemoglobin (Hb), Packed Cell Volume (PCV), Neutrophil and Eosinophil count were significantly lower among the hypertensive subjects compared to non-hypertensive controls ( $\mathrm{p}<0.01, \mathrm{p}<0.01, \mathrm{p}=0.02, \mathrm{p}<$ 0.01 and $\mathrm{p}<0.01)$ respectively. The Red cell count $(\mathrm{RBC})$, lymphocyte and monocyte count were significantly higher among the hypertensive subjects compared to the non-hypertensive controls $(\mathrm{p}=0.00)$. There were no statistically significant differences in the Red cell distribution width (RDW), platelet and basophil count of the hypertensive subjects and the non-hypertensive controls $(\mathrm{p}>0.05)$

Table 2 shows the effect of the different stages of hypertension on the full blood count parameters of hypertensive subjects. RBC, Hb, RDW and Platelets show a statistical significance with difference stages of hypertension $(\mathrm{p}<0.05)$. There was a statistically significant difference in the RBC, $\mathrm{Hb}$ and Monocyte.

Table 3 shows the FBC of hypertensive patients in the study groups based on Age; (male and female). There was a statistically significant difference in the 
PCV and platelets parameters among hypertensive patients $(\mathrm{p}<0.05)$. There was no statistical difference in $\mathrm{WBC}, \mathrm{RBC}, \mathrm{Hb}, \mathrm{RDW}$, Monocytes, Basophils among hypertensive subjects $(\mathrm{p}>0.05)$.

Table 4 shows the FBC parameters among hypertensive patients based on gender (male and female). There was a statistically significant difference in the RBC ( $\mathrm{p}<0.05), \mathrm{Hb}(\mathrm{p}<0.02)$ and Monocyte $(\mathrm{p}<0.04)$ among hypertensive patients based on gender. There was no statistical difference in WBC, PCV, RDW, Monocytes, Basophils, Manganese, Neutrophil, lymphocytes, and platelet parameters among hypertensive subjects ( $\mathrm{p}>0.05)$.

Table 5 shows the FBC of hypertensive patients in the study groups based on ethnicity. There was a statistically significant difference in the monocytes, parameter among hypertensive patients based on ethnicity $(\mathrm{p}<0.05)$. There was no statistical difference in the other full blood count parameter and trace elements among hypertensive subjects ( $\mathrm{p}>0.05)$.

Table 1. Full blood count parameters among the subjects and controls.

\begin{tabular}{ccccc}
\hline Parameters & $\begin{array}{c}\text { Hypertensive } \\
\text { subjects (60) } \\
\text { Mean } \pm \text { SD }\end{array}$ & $\begin{array}{c}\text { Controls (30) } \\
\text { Mean } \pm \text { SD }\end{array}$ & t-value & p-value \\
\hline WBCC $\left(\times 10^{3} / \mu \mathrm{l}\right)$ & $5.33 \pm 1.79$ & $6.96 \pm 2.21$ & -3.75 & $<0.01$ \\
RBCC $\left(\times 10^{6} / \mu \mathrm{l}\right)$ & $4.79 \pm 0.97$ & $3.21 \pm 0.63$ & 8.08 & $<0.01$ \\
Hb $(\mathrm{g} / \mathrm{dl})$ & $12.18 \pm 2.01$ & $13.95 \pm 1.66$ & -4.16 & $<0.01$ \\
PCV $(\%)$ & $36.45 \pm 6.39$ & $39.74 \pm 5.85$ & -2.37 & 0.02 \\
RDW $(\%)$ & $13.95 \pm 1.86$ & $14.03 \pm 2.53$ & -0.16 & 0.87 \\
Platelet $\left(\times 10^{3} / \mu \mathrm{l}\right)$ & $277.12 \pm 90.39$ & $272.03 \pm 108.78$ & 0.24 & 0.82 \\
Lymphocyte $(\%)$ & $48.07 \pm 14.07$ & $38.14 \pm 7.12$ & 3.63 & $<0.01$ \\
Monocyte $(\%)$ & $9.04 \pm 4.19$ & $4.82 \pm 1.96$ & 5.23 & $<0.01$ \\
Neutrophil $(\%)$ & $51.03 \pm 14.77$ & $60.17 \pm 9.68$ & -3.07 & $<0.01$ \\
Eosinophil $(\%)$ & $1.99 \pm 2.11$ & $3.67 \pm 1.40$ & -3.95 & $<0.01$ \\
Basophil $(\%)$ & $0.49 \pm 0.42$ & $0.57 \pm 0.29$ & -0.89 & 0.38 \\
\hline
\end{tabular}

Table 2. Effect of the different stages of hypertension on the FBC parameters.

\begin{tabular}{cccccc}
\hline Parameters & Stages & N & Mean \pm SD & f-value & p-value \\
\hline \multirow{2}{*}{ White Blood Cells } & Stage 1 & 2 & $5.10 \pm 0.98$ & & \\
& Stage 11 & 16 & $5.72 \pm 0.87$ & 0.52 & 0.59 \\
& Stage 111 & 42 & $5.19 \pm 2.06$ & & \\
Red Blood Cells & Stage 1 & 2 & $5.50 \pm 0.42$ & & \\
& Stage 11 & 16 & $5.32 \pm 0.69$ & 4.78 & 0.01 \\
& Stage 111 & 42 & $4.55 \pm 0.98$ & & \\
Haemoglobin & Stage 1 & 2 & $13.65 \pm 0.35$ & & \\
& Stage 11 & 16 & $10.68 \pm 1.50$ & 7.66 & $<0.01$ \\
& Stage 111 & 42 & $12.68 \pm 1.94$ & & \\
\hline
\end{tabular}




\section{Continued}

\begin{tabular}{|c|c|c|c|c|c|}
\hline & Stage 1 & 2 & $38.10 \pm 6.93$ & & \\
\hline \multirow[t]{3}{*}{ PCV (\%) } & Stage 11 & 16 & $37.39 \pm 4.37$ & 0.335 & 0.72 \\
\hline & Stage 111 & 42 & $36.00 \pm 7.07$ & & \\
\hline & Stage 1 & 2 & $216.00 \pm 25.46$ & & \\
\hline \multirow[t]{3}{*}{ Platelet } & Stage 11 & 16 & $335.50 \pm 68.25$ & 5.47 & 0.01 \\
\hline & Stage 111 & 42 & $257.79 \pm 90.23$ & & \\
\hline & Stage 1 & 2 & $9.60 \pm 5.09$ & & \\
\hline \multirow[t]{3}{*}{ Monocyte } & Stage 11 & 16 & $8.26 \pm 3.99$ & 0.37 & 0.68 \\
\hline & Stage 111 & 42 & $9.31 \pm 4.30$ & & \\
\hline & Stage 1 & 2 & $44.60 \pm 13.58$ & & \\
\hline \multirow[t]{3}{*}{ Lymphocyte } & Stage 11 & 16 & $47.38 \pm 13.07$ & 0.09 & 0.90 \\
\hline & Stage 111 & 42 & $48.49 \pm 14.58$ & & \\
\hline & Stage 1 & 2 & $61.10 \pm 7.07$ & & \\
\hline \multirow[t]{3}{*}{ Neutrophil } & Stage 11 & 16 & $52.49 \pm 16.93$ & 0.63 & 0.53 \\
\hline & Stage 111 & 42 & $50.00 \pm 14.17$ & & \\
\hline & Stage 1 & 2 & $0.75 \pm 0.21$ & 0.40 & 0.668 \\
\hline \multirow[t]{3}{*}{ Eosinophil } & Stage 11 & 16 & $2.18 \pm 2.17$ & & \\
\hline & Stage 111 & 42 & $1.97 \pm 2.14$ & & \\
\hline & Stage 1 & 2 & $0.75 \pm 0.71$ & & \\
\hline \multirow[t]{3}{*}{ Basophil } & Stage 11 & 16 & $0.45 \pm 0.26$ & 0.46 & 0.63 \\
\hline & Stage 111 & 42 & $0.49 \pm 0.47$ & & \\
\hline & Stage 1 & 2 & $13.00 \pm 0.85$ & & \\
\hline \multirow[t]{2}{*}{$\begin{array}{l}\text { Red Cell Distribution } \\
\text { Width }\end{array}$} & Stage 11 & 16 & $12.68 \pm 1.47$ & 6.82 & $<0.01$ \\
\hline & Stage 111 & 42 & $14.48 \pm 1.79$ & & \\
\hline
\end{tabular}

Table 3. FBC parameters among hypertensive subjects by age.

\begin{tabular}{cccccc}
\hline Parameters & Age (Years) & N & Mean \pm SD & t-value & p-value \\
\hline White Blood Cells & $<40$ & 4 & $5.07 \pm 2.24$ & -0.29 & 0.77 \\
& $>40$ & 56 & $5.35 \pm 1.78$ & & 0.38 \\
Red Blood Cells & $<40$ & 4 & $4.37 \pm 1.39$ & -0.88 & 0.24 \\
Haemoglobin & $>40$ & 56 & $4.82 \pm 0.94$ & & -1.16 \\
PCV (\%) & $<40$ & 4 & $11.05 \pm 3.23$ & & 0.02 \\
& $>40$ & 56 & $12.26 \pm 1.91$ & & \\
Platelet & $<40$ & 4 & $29.50 \pm 10.71$ & -2.33 & \\
& $>40$ & 56 & $36.94 \pm 5.82$ & & 0.01 \\
& $<40$ & 4 & $174.00 \pm 57.78$ & -2.46 &
\end{tabular}




\section{Continued}

\begin{tabular}{cccccc}
\hline Monocyte & $<40$ & 4 & $7.87 \pm 4.38$ & -0.57 & 0.56 \\
& $>40$ & 56 & $9.12 \pm 4.20$ & & \\
Lymphocyte & $<40$ & 4 & $40.90 \pm 10.51$ & -1.05 & 0.29 \\
& $>40$ & 56 & $48.57 \pm 14.22$ & & \\
Neutrophil & $<40$ & 4 & $58.70 \pm 5.62$ & 1.07 & 0.28 \\
Eosinophil & $>40$ & 56 & $50.48 \pm 15.19$ & & \\
Basophil & $<40$ & 4 & $0.47 \pm 0.34$ & -1.50 & 0.13 \\
& $>40$ & 56 & $2.09 \pm 2.13$ & & \\
Red Cell Distribution & $<40$ & 4 & $0.60 \pm 0.22$ & 0.52 & 0.60 \\
Width & $>40$ & 56 & $0.48 \pm 0.43$ & & \\
& $>40$ & 4 & $14.23 \pm 1.73$ & 0.304 & 0.76 \\
& $>40$ & 56 & $13.93 \pm 1.88$ & &
\end{tabular}

Table 4. FBC parameters among hypertensive subjects based on gender.

\begin{tabular}{ccccc}
\hline Parameters & $\begin{array}{c}\text { Male (30) } \\
\text { Mean } \pm \text { SD }\end{array}$ & $\begin{array}{c}\text { Female (30) } \\
\text { Mean } \pm \text { SD }\end{array}$ & t-value & p-value \\
\hline WBCC $\left(\times 10^{3} / \mu \mathrm{l}\right)$ & $5.52 \pm 1.64$ & $5.14 \pm 1.94$ & 0.81 & 0.42 \\
RBCC $\left(\times 10^{6} / \mu \mathrm{l}\right)$ & $4.54 \pm 0.78$ & $5.03 \pm 1.08$ & -2.03 & 0.05 \\
Hb $(\mathrm{g} / \mathrm{dl})$ & $12.77 \pm 1.57$ & $11.58 \pm 2.24$ & 2.38 & 0.02 \\
PCV $(\%)$ & $35.74 \pm 6.52$ & $37.16 \pm 6.29$ & -0.86 & 0.39 \\
RDW $(\%)$ & $14.02 \pm 1.65$ & $13.88 \pm 2.07$ & 0.28 & 0.78 \\
Platelet $\left(\times 10^{3} / \mu \mathrm{l}\right)$ & $287.03 \pm 73.49$ & $267.20 \pm 104.96$ & 0.85 & 0.40 \\
Lymphocyte $(\%)$ & $49.73 \pm 14.96$ & $46.40 \pm 13.15$ & 0.92 & 0.36 \\
Monocyte $(\%)$ & $10.13 \pm 4.23$ & $7.96 \pm 3.92$ & 2.06 & 0.04 \\
Neutrophil $(\%)$ & $49.70 \pm 14.56$ & $52.36 \pm 15.10$ & -0.69 & 0.49 \\
Eosinophil $(\%)$ & $2.22 \pm 2.17$ & $1.76 \pm 2.05$ & 0.85 & 0.40 \\
Basophil $(\%)$ & $0.57 \pm 0.54$ & $0.42 \pm 0.23$ & 1.39 & 0.17 \\
\hline
\end{tabular}

Table 5. FBC parameters among hypertensive subjects by ethnic group.

\begin{tabular}{|c|c|c|c|c|c|}
\hline $\begin{array}{c}\text { Haematological } \\
\text { Ethnicity }\end{array}$ & Parameter & $\mathbf{N}$ & Mean $\pm S D$ & t-value & p-value \\
\hline \multirow{2}{*}{ White Blood Cells } & Hausa & 48 & $5.21 \pm 1.69$ & 0.21 & 0.83 \\
\hline & Fulani & 5 & $5.04 \pm 2.31$ & & \\
\hline \multirow{2}{*}{ Red Blood Cells } & Hausa & 48 & $4.83 \pm 0.76$ & 1.41 & 0.16 \\
\hline & Fulani & 5 & $4.30 \pm 1.16$ & & \\
\hline \multirow{2}{*}{ Haemoglobin } & Hausa & 48 & $12.20 \pm 1.90$ & 0.56 & 0.58 \\
\hline & Fulani & 5 & $11.68 \pm 2.67$ & & \\
\hline \multirow{2}{*}{ PCV (\%) } & Hausa & 48 & $36.57 \pm 6.17$ & 0.80 & 0.42 \\
\hline & Fulani & 5 & $34.18 \pm 8.19$ & & \\
\hline
\end{tabular}




\begin{tabular}{cccccc} 
Continued & & & & & \\
\hline \multirow{2}{*}{ Platelet } & Hausa & 48 & $280.06 \pm 93.07$ & 1.06 & 0.29 \\
& Fulani & 5 & $233.20 \pm 105.92$ & & \\
Monocyte & Hausa & 48 & $9.27 \pm 4.22$ & 2.79 & $<0.01$ \\
& Fulani & 5 & $3.90 \pm 1.92$ & & \\
Lymphocyte & Hausa & 48 & $49.24 \pm 13.73$ & 0.18 & 0.85 \\
& Fulani & 5 & $48.04 \pm 18.26$ & & \\
Neutrophil & Hausa & 48 & $52.60 \pm 14.44$ & 1.37 & 0.18 \\
& Fulani & 5 & $43.16 \pm 16.79$ & & \\
Eosinophil & Hausa & 48 & $1.85 \pm 2.04$ & 0.86 & 0.39 \\
& Fulani & 5 & $1.05 \pm 0.76$ & & \\
Basophil & Hausa & 48 & $0.53 \pm 0.45$ & 1.09 & 0.28 \\
& Fulani & 5 & $0.31 \pm 0.11$ & & \\
RDW & Hausa & 48 & $13.82 \pm 1.79$ & -0.27 & 0.79 \\
& Fulani & 5 & $14.04 \pm 1.39$ & & \\
\hline
\end{tabular}

\section{Discussion}

Hypertension is a major health problem worldwide. It can lead to cardiovascular disease and also leads to functional disturbances including haematological parameters. The aim of this study was to assess some haematological parameters of hypertensive individuals in comparison with normotensive individuals.

In this study the mean value for $\mathrm{Hb}$ was shown to be lower among hypertensive compared to normotensive subjects $(p>0.05)$. Our finding agrees with the finding in a previous study conducted in São Paulo, Brazil [31]. Our finding is however at variance with previous report [32] which shows that $\mathrm{Hb}$ value was significantly increased in the hypertensive group compared to normotensive groups. The association between HTN and Hgb level may be explained by Hgb and arginase enzyme effects on nitric oxide (NO) bioavailability [32]. Normocytic anaemia is common among hypertensive patients. Lower haemoglobin concentrations were found in patients with uncontrolled than among those with well controlled hypertension, indicating a higher cardiovascular risk in uncontrolled hypertension. Patients with anaemia had higher nocturnal systolic and mean blood pressure and a tendency for increased diastolic blood pressure and lower dipping status compared to patients with normal haemoglobin levels. Leptin, the product of the human obesity gene, might be involved in the regulation of the rheologic behavior of erythrocytes and the microcirculation in hypertension. Anaemia is associated with higher cardiovascular risk, higher blood pressure values, and lower dipping status in hypertensive patients, and haemoglobin should be monitored in hypertensive patients [33]. During HTN, there is a possibility of haemolysis [34] [35] [36] [37]. Previous studies suggest that hypertension is a complication of hemolysis and associated with haemolytic anaemia [38]. During haemolysis, haemoglobin and arginase enzyme are released in to circulation from erythrocytes. This free haemoglobin is a scavenger of nitric 
oxide which is produced in the endothelial cell that lines the blood vessels which is important for relaxation of blood vessels. On the other hand, arginase enzyme depletes the substrate used for NO synthesis by conversion of arginine to ornithine, thus reducing NO production [39].

Our finding is consistent with a previous report which indicated that haematological parameters are impaired [40] and may strongly indicate hypertensive end-organ damage, specifically kidney failure [41] [42]. Specifically, increased $\mathrm{Hb}$ level may cause left ventricular hypertrophy while low Hgb levels causes anemia and heart failure [43].

We observed that the White Cell Count (WBC) was significantly lower among the hypertensive subjects compared to non-hypertensive controls. Our finding is consistent with a previous report which showed a lower mean value of WBC count in hypertensive individuals when compared to apparently healthy normotensive subjects [44] [45]. In two community studies that adjusted for such coronary risk factors, the WBC count was no longer associated with elevated coronary risk. Elevated WBC count has been associated with high blood pressure (BP) [46].

We observed that there were no significant differences between the platelet count of hypertensive subjects and controls. Our finding agrees with findings in a previous study [47]. During hypertension, there is endothelial dysfunction and this leads to platelet activation and clot formation. Then platelets will be consumed and the number does not increase as expected [48]. When platelet production is induced, there could be increment in platelet count. Evidence suggests that platelet consumption increase at the site of injured blood vessel. During this condition larger platelets would be released from the bone marrow because larger platelets are haemostatically more active than mature platelets. Platelets have central role in pathophysiology of athero-thrombotic cardiovascular diseases. Increased MPV has been shown in patients with cardiovascular diseases and in patients' groups with known coronary artery disease risk factors. Moreover, increased MPV has also prognostic role in cardio-vascular diseases, for example, it is associated with higher mortality following myocardial infarction [31].

The result obtained from this study showed that the mean value of RDW was not significantly lower among hypertensive subject compared to non-hypertensive subject ( $\mathrm{p}=0.87$ ). Our finding is disagreement with previous report [44] which shows that the hypertensive groups had significantly higher mean (SD) value of RDW ( $<0.05$ ). RDW increased significantly in hypertensive groups compared to normotensive individuals. Most studies suggest that higher RDW, which is a measure of the variability in the circulating erythrocytes' size, may result from ineffective erythropoiesis due to chronic inflammation during hypertension [42].

\section{Conclusion and Recommendation}

The findings from this study indicate that the (WBC), packed cell volume (PCV) haemoglobin $(\mathrm{Hb})$, neutrophils and eosinophils are significantly lower among 
hypertensive subjects compared to non-hypertensive controls. Stage of the disease, age, gender and ethnicity have a significant effect on the full blood count parameters of hypertensive patients. There is need to step up public enlightenment programme to educate hypertensive patients on the need for attending clinic regularly for effective follow up. It is recommended that routine monitoring of FBC parameters among hypertensive in the area be carried out and used to monitor the prognosis of the disease and to manage hypertensive related complications.

\section{Limitations}

The main limitation is that a higher number of hypertensive subjects could have been studied. There may be need to carry out a larger multicenter and regional study in future.

\section{Conflicts of Interest}

Authors confirm that there is no conflict of interest associated with this manuscript.

\section{References}

[1] James, P.A., Oparil, S., Carter, B.L., Cushman, W.C. and Dennison-Himmelfard, C. (2013) Evidence-Based Guideline for the Management of High Blood Pressure in Adults: Report from the Panel Members Appointed to the Eighth Joint National Committee (JNC 8). Journal of American Medical Association, 311, 507-520. https://doi.org/10.1001/jama.2013.284427

[2] Rastogi, D., Ngai, P., Barst, R.J. and Koumbourlis, A.C. (2004) Lower Airway Obstruction, Bronchial Hyperresponsiveness, and Primary Pulmonary Hypertension in Children. Paediatric Pulmonology, 37, 50-55.

[3] Chobanian, A.V., Bakris, G.L., Black, H.R., Cushman, W.C. and Izzo, J.L. (2003) The Seventh Report of the National Committee on Prevention, Detection, Evaluation, and Treatment of High Blood Pressure. Hypertension, 42, 1206-1252. https://doi.org/10.1161/01.HYP.0000107251.49515.c2

[4] Kearney, P.M., Whelton, M., Reynolds, K., Muntner, P., Whelton, P.K. and He, J. (2005) Global Burden of Hypertension: Analysis of Worldwide Data. The Lancet, 365, 217-223. https://doi.org/10.1016/S0140-6736(05)17741-1

[5] Adeloye, D., Basquill, C., Aderemi, A.V., Thompson, J.Y. and Obi, F.A. (2015) An Estimate of the Prevalence of Hypertension in Nigeria: A Systematic Review and Meta-Analysis. Journal of Hypertension, 33, 230-242. https://doi.org/10.1097/HJH.0000000000000413

[6] Beaglehole, R., Bonita, R., Alleyne, G., Horton, R., Li, L., Lincoln, P., Mbanya, J.C., McKee, M., Moodie, R., Nishtar, S., Piot, P., Reddy, K.S., Stuckler, D., Lancet, N.C.D. and Action Group (2011) UN High-Level Meeting on Non-Communicable Diseases: Addressing Four Questions. The Lancet, 378, 449-455. https://doi.org/10.1016/S0140-6736(11)60879-9

[7] World Health Organization (2013) A Global Brief on Hypertension: Silent Killer, Global Public Health Crises (World Health Day 2013). WHO, Geneva. http://apps.who.int/iris/bitstream/10665/79059/1/WHO_DCO_WHD_2013.2_eng. pdf 
[8] Kayima, J., Wanyenze, R.K., Katamba, A., Leontsini, E. and Nuwaha, F. (2013) Hypertension Awareness, Treatment and Control in Africa: A Systematic Review. BMC Cardiovascular Disorder, 13, 54. https://doi.org/10.1186/1471-2261-13-54

[9] Perkovic, V., Huxley, R., Wu, Y., Prabhakaran, D. and MacMahon, S. (2007) The Burden of Blood Pressure-Related Disease: A Neglected Priority for Global Health. Hypertension, 50, 991-997. https://doi.org/10.1161/HYPERTENSIONAHA.107.095497

[10] Ukwaja, K.N. and Onyedum, C.C. (2013) Reaction to O.S. Ilesanmi, the Managed Hypertensive: The Costs of Blood Pressure Control in a Nigerian Town. Pan African Medical Journal, 14, 85.

[11] Ekpenyong, C.E., Udokang, N.E., Akpan, E.E. and Samson, T.K. (2012) Double Burden, Non-Communicable Diseases and Risk Factors Evaluation in Sub-Saharan Africa: The Nigerian Experience. European Journal of Sustainable Development, 1, 249-270.

[12] Ilesanmi, O.S., Ige, O.K. and Adebiyi, A.O. (2012) The Managed Hypertensive: The Costs of Blood Pressure Control in a Nigerian Town. Pan African Medical Journal, $12,96$.

[13] Ogah, O.S., Okpechi, I., Chukwuonye, I.I., Akinyemi, J.O., Onwubere, B.J.C., Falase, A.O., Stewart, S. and Sliwa, K. (2012) Blood Pressure, Prevalence of Hypertension and Hypertension Related Complications in Nigerian Africans: A Review. World Journal Cardiology, 4, 327-340. https://doi.org/10.4330/wjc.v4.i12.327

[14] Abegunde, D.O., Mathers, C.D., Adam, T., Ortegon, M. and Strong, K. (2007) Chronic Diseases 1: The Burden and Costs of Chronic Diseases in Low-Income and Middle-Income Countries. The Lancet, 370, 1929-1938. https://doi.org/10.1016/S0140-6736(07)61696-1

[15] Cooper, R.S., Liao, Y. and Rotimi, C. (1996) Is Hypertension More Severe among U.S. Blacks, or Is Severe Hypertension More Common? Annals of Epidemiology, 6, 173-180. https://doi.org/10.1016/1047-2797(96)00009-9

[16] Oladapo, O.O., Salako, L., Sodiq, O., Shoyinka, K., Adedapo, K. and Falase, A.O. (2010) A Prevalence of Cardiometabolic Risk Factors among a Rural Yoruba South-Western Nigerian Population: A Population-Based Survey. Cardiovascular Journal of Africa, 21, 26-31.

[17] Ulasi, I.I., Ijoma, C.K., Onwubere, B.J., Arodiwe, E., Onodugo, O. and Okafor, C. (2011) High Prevalence and Low Awareness of Hypertension in a Market Population in Enugu, Nigeria. International Journal of Hypertension, 2011, Article ID: 869675. https://doi.org/10.4061/2011/869675

[18] Ekwunife, O.I., Udeogaranya, P.O. and Nwatu, I.L. (2010) Prevalence, Awareness, Treatment and Control of Hypertension in a Nigerian Population. Health, 7, 731-735. https://doi.org/10.4236/health.2010.27111

[19] George-Gay, B. and Parker, K. (2003) Understanding the Complete Blood Count with Differential. Journal of PeriAnesthesia Nursing, 18, 96-114. https://doi.org/10.1053/jpan.2003.50013

[20] Yusuf, S., Reddy, S. and Anand, S. (2001) Global Burden of Cardiovascular Diseases. Part 1: General Consideration, the Epidemiologic Transient, Risk Factor and Impact of Urbanization. Circulation, 104, 2746-2753. https://doi.org/10.1161/hc4601.099487

[21] Singh, R.B., Suh, I.L., Singh, V.P., Chaitiraphan, S., Laothavorn, P., Sy, R.G., Babilonia, N.A., Rahman, A.R., Sheikh, S., Tomlinson, B. and Sarraf-Zadigan, N. (2000) Hypertension on Stroke in Asia; Prevalence, Control and Strategies in Developing 
Countries for Prevention. Journal of Human Hypertension, 14, 749-763. https://doi.org/10.1038/sj.jhh.1001057

[22] Voster, H.H. (2002) The Emergent of Cardiovascular Disease during Urbanization of Africa. Public Health Nutrition, 5, 239-243. https://doi.org/10.1079/PHN2001299

[23] Khor, G.L. (2001) Cardiovascular Epidemiology Asia-Pacific Region. Asia Pacific Journal Clinical Nutrition, 10, 76-80. https://doi.org/10.1046/j.1440-6047.2001.00230.x

[24] Colins, R., Peto, R., Macmahon, S., Herbert, P. and Fiebach, N.H. (1990) Blood Pressure, Stroke and Coronary Heart Disease Part 2: Overview of Randomized Drug Trials in Their Epidemiological Context. The Lancet, 335, 827-838. https://doi.org/10.1016/0140-6736(90)90944-Z

[25] Federal Ministry of Health and Social Services, Lagos. National Expert Committee on Non-Communicable Disease in Nigeria, 1997.

[26] Wokoma, F.S. and Alasia, D.D. (2011) Blood Pressure Pattern in Barako: A Rural Community in Rivers State, Nigeria. Nigerian Health Journal, 11, 8-13.

[27] Ordinioha, B. and Brisibe, S. (2011) Prevalence of Hypertension and Its Modifiable Risk Factors amongst Traditional Chiefs of an Oil-Bearing Community in South-South Nigeria. Sahel Medical Journal, 16, 24-27. https://doi.org/10.4103/1118-8561.112065

[28] Omuemu, V.O., Okojie, O.H. and Omuemu, C.E. (2007) Awareness of High Blood Pressure Status, Treatment and Control in a Rural Community in Edo State. Nigerian Journal of Clinical Practice, 10, 208-212.

[29] NPC/FGN Nigerian Population Commission, Federal Republic of Nigeria (2006) Special FGN Gazette No. 23 on the 2006 Population Census.

[30] Ejike, C.E.C.C., Ugwu, C.E. and Ezeanyika, L.U.S. (2010) Variations in the Prevalence of Point (Pre) Hypertension in a Nigerian School-Going Adolescent Population Living in a Semi-Urban and an Urban Area. BMC Pediatrics, 10, 13. https://doi.org/10.1186/1471-2431-10-13

[31] Enawgaw, B., Adane, N., Terefe, B., Asrie, F. and Melku, M. (2017) A Comparative Cross-Sectional Study of Some Hematological Parameters of Hypertensive and Normotensive Individuals at the University of Gondar Hospital, Northwest Ethiopia. BMC Hematology, 17, 21. https://doi.org/10.1186/s12878-017-0093-9

[32] Hua, R., Cao, H. and Wu, Z.Y. (2006) Effects of Hemoglobin Concentration on Hyperdynamic Circulation Associated with Portal Hypertension. Hepatobiliary Pancreatic Disease International, 5, 215-218.

[33] Mozos, I. (2015) Mechanisms Linking Red Blood Cell Disorders and Cardiovascular Diseases. BioMed Research International, 2015, Article ID: 682054. https://doi.org/10.1155/2015/682054

[34] Brittain, E.L., Janz, D.R., Austin, E.D., Bastarache, J.A., Wheeler, L.A., Ware, L.B., et al. (2014) Elevation of Plasma Cell-Free Hemoglobin in Pulmonary Arterial Hypertension. Chest, 146, 1478-1485. https://doi.org/10.1378/chest.14-0809

[35] Wahl, S. and Vichinsky, E. (2010) Pulmonary Hypertension in Hemolytic Anemias. F1000 Medicine Reports, 2, 10. https://doi.org/10.3410/M2-10

[36] Bruschi, G., Minari, M., Bruschi, M.E., Tacinelli, L., Milani, B., Cavatorta, A., et al. (1986) Similarities of Essential and Spontaneous Hypertension. Volume and Number of Blood Cells. Hypertension, 8, 983-989. https://doi.org/10.1161/01.HYP.8.11.983

[37] Mathew, R., Huang, J., Fallon, J.T. and Gewitz, M.H. (2016) Hematological Disord- 
ers and Pulmonary Hypertension. World Journal of Cardiology, 8, 703-718. https://doi.org/10.4330/wjc.v8.i12.703

[38] Jadeja, U., Jadeja, J. and Naik, S. (2011) Comparative Study of Haemoglobin Concentration in Hypertensive and Normotensive Subjects. Indian Journal of Applied Basic Medical Sciences, 13, 7.

[39] Babu, K.R., Kumar, N.L.G., Solepure, A.B. and Shaikh, R. (2015) Comparison of Haematological Parameters in Primary Hypertensives and Normotensives of Sangareddy. International Journal of Biomedical Research, 6, 309-315. https://doi.org/10.7439/ijbr.v6i5.1994

[40] Smebye, M.L., Iversen, E.K., Høieggen, A., Flaa, A., Os, I., Kjeldsen, S.E., et al. (2007) Effect of Hemoglobin Levels on Cardiovascular Outcomes in Patients with Isolated Systolic Hypertension and Left Ventricular Hypertrophy (from the LIFE Study). American Journal of Cardiology, 100, 855-859. https://doi.org/10.1016/j.amjcard.2007.03.109

[41] Karabulut, A. and Karadag, A. (2015) Clinical Implication of Hematological Indices in the Essential Hypertension. World Journal of Hypertension, 5, 93-97. https://doi.org/10.5494/wjh.v5.i2.93

[42] Reis, R.S., Benseñor, I.J. and Lotufo, P.A. (1999) Laboratory Assessment of the Hypertensive Individual. Value of the Main Guidelines for High Blood Pressure. Arquivos Brasileiros de Cardiologia, 73, 201-210. https://doi.org/10.1590/S0066-782X1999000800008

[43] Schillaci, G., Pirro, M., Pucci, G., Ronti, T., Vaudo, G., Mannarino, M.R., Porcellati, C. and Mannarino, E. (2018) Prognostic Value of Elevated White Blood Cell Count in Hypertension. American Journal of Hypertension, 20, 364-369. https://doi.org/10.1016/j.amjhyper.2006.10.007

[44] Sahin, I., Karabulut, A., Avci, I.I., Okuyan, E., Biter, H.I. and Yildiz, S.S. (2015) Contribution of Platelets Indices in the Development of Contrast-Induced Nephropathy. Blood Coagulation Fibrinolysis, 26, 246-249. https://doi.org/10.1097/MBC.0000000000000107

[45] Yaghoubi, A., Golmohamadi, Z., Alizadehasl, A. and Azarfarin, R. (2013) Role of Platelet Parameters and Haematological Indices in Myocardial Infarction and Unstable Angina. Journal of the Pakistan Medical Association, 63, 1133-1137.

[46] Varol, E., Uysal, B.A. and Ozaydin, M. (2011) Platelet Indices in Patients with Pulmonary Arterial Hypertension. Clinical and Applied Thrombosis/Hemostasis, 17, E171-E174.

[47] Fornal, M., Wizner, B., Cwynar, M., Królczyk, J., Kwater, A. and Korbut, R.A. (2013) Association of Red Blood Cell Distribution Width, Inflammation Markers and Morphological as Well as Rheological Erythrocyte Parameters with Target Organ Damage in Hypertension. Clinical Hemorheological Microcirculation, 56, 325-335.

[48] Inanc, T., Kaya, M.G., Yarlioglues, M., Ardic, I., Ozdogru, I. and Dogan, A. (2010) The Mean Platelet Volume in Patients with Non-Dipper Hypertension Compared to Dippers and Normotensives. Blood Pressure, 19, 81-85.

https://doi.org/10.3109/08037050903516284 